\title{
Analysis of the Patterns of Trade Cooperation of Agricultural Products between China and ASEAN
}

\author{
Jie Feng ${ }^{1, a,{ }^{*}}$ \\ ${ }^{1}$ Business School of HoHai University, China \\ afengjieg@163.com \\ ${ }^{*}$ Corresponding author
}

Keywords: Agricultural products, dual patterns, cooperation

\begin{abstract}
Based on the scholars' research on the trade of agricultural products between China and ASEAN (Association of Southeast Asian Nations), this paper analyzes the competitiveness and complementarity of current agricultural trade between China and ASEAN and points out the reason for its existence. Finally, the paper suggests some measures which can will promote cooperation in the bilateral trade.
\end{abstract}

\section{Introduction}

CAFTA (China-ASEAN Free Trade Area) was established on January 1, 2010. In 2015 China will build a free trade area with new members of ASEAN which will be a tariff-free trade area except for sensitive products. Furthermore, all goods are free tariffs including sensitive products in 2018. In that case, ASEAN Free Trade Area will have 1.9 billion consumers, and become the world's third largest free trade zone with the gross domestic product more than $\$ 2$ trillion. Meanwhile, with the growing volume of Chinese agricultural products trade, the deficit continues to increase which has also affected Chinese economy to some extent. So it's necessary to study China-ASEAN dual pattern of trade cooperation of agricultural products.

\section{Literature Review}

The similarities in the level of development, infrastructure, technology and geographic location between the member countries of ASEAN and China make their trade structure become similar. The strong competitiveness of both sides promotes bilateral agricultural trade.

Jinping Yu (2003) considered China had a large disadvantage in the primary products, and the basis of agricultural products trade between China and ASEAN is the bilateral competitive relations. More competition brings more profits. Roeblano M. Briones and Danilo C. Israel (2014) found that the complementary relations in agricultural products between China and ASEAN only account for small proportion, but the proportion of competition has continued to strengthen. For example, ASEAN improves the movement of goals from farms to firms and consumers domestically and regionally, thereby moving towards a single production base in agricultural product in the ASEAN region. Xianli Xia and Xueli Wu (2010) pointed out that, with a substantial increasing in the volume of trade, exports of agricultural products have increased since China joined the WTO, but the growth of export was less than the growth of import and there is a deficit phenomenon which tends to widen. Zhiyu Shi (2004) calculated the trade volume of agricultural products between China and ASEAN which shows a strong complementary relationship and the convergence trend of the bilateral exports. Shuquan Huang and Xiguo Yin (2005) found the complementary agricultural products which Chinese exports to ASEAN will increase to a relatively high level, and non-complementary parts will reduce to a lower level. Lingli Lv (2006) studied the agricultural 
products trade from the perspective of the nation competition. She considered that the member countries of ASEAN such as Philippines, Vietnam, and Thailand are intensely competing with China. Malaysia and Indonesia have a high similarity with China in vegetables and aquatic products market which led to a large competition. In the case, China and ASEAN should make specialized division of labor for agricultural products to improve the cooperation possibilities. Hongjian Zhang and Jinbo He (2009) considered that the development of agriculture in China is inseparable from the massive exports which are also conductive to promote Chinese agricultural products trade. By analyzing the structure and the benefits of agricultural products trade in CAFTA, Chao $\mathrm{Hu}$ and Jianghai Lu (2009) thought that China should rely on its own agricultural products which have comparative advantages and actively cooperate with member countries of ASEAN in a higher lever of agriculture. China and ASEAN are supposed to make efforts to establish a common agricultural market. Jianghong Zhao (2010) analyzed the effect of ASEAN's trade with China and found that the positive impact of trade between China and CAFTA is greater than the negative impact.

In summary, we can draw a conclusion from the above literature, scholars are widely concerned about the pattern of trade cooperation of agricultural products between China and ASEAN, but only focused on a particular aspect of competitiveness or complementarity. The paper has analyzed the bilateral trade cooperation from the dual pattern.

\section{Status of Agricultural Trade between China and ASEAN}

The Total Bilateral Trade Keeps Rising with Diversified Patterns. Since CAFTA officially launched in 2010, the bilateral trade has been a huge development, as shown in Fig. 1. The total trade is $\$ 3.03$ billion in 2001, and increased to $\$ 27.55$ billion in 2011 which has almost increased 9.1 times. In the Chinese imports of agricultural products from ASEAN, the proportion of animal oil, timber and its processed products reduced to about $50 \%$, but other varieties have been improved. The proportion of fish, fruit and vegetables, sugar and cereals separately accounted for $13 \%, 13 \%$, $6.5 \%$ and $5.5 \%$. In the Chinese exports of agricultural products to ASEAN, the proportion of processed foods, fruits and vegetables, and cereals separately accounted for $37 \%, 28 \%$ and $17 \%$. The bilateral agricultural trade species have emerged diversity patterns.

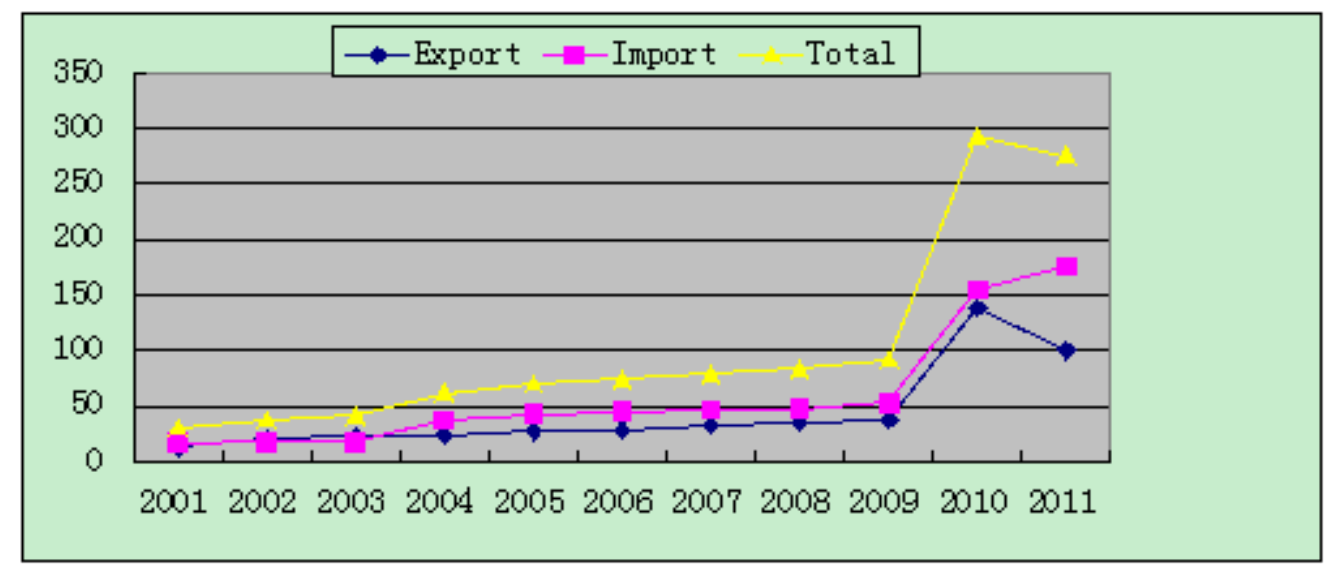

Fig. 1 The trend of the Chinese agricultural products trade with ASEAN Data source: Chinese Customs

Chinese Agricultural Trade with ASEAN Has Deficit in the Long-term. Facing Chinese vast market, ASEAN keep expanding agricultural exports to China, so that the bilateral trade volume continues to rise which makes the deficit tend to increase. As it shows in Fig. 2, in the long term, 
the deficit of the agricultural trade between China and ASEAN is a major part of the deficit of Chinese agricultural products global trade which accounts for about 25\%. From 2004 to 2011, the annual average deficit has reached to $\$ 2.2$ billion. Among the ten member countries, China has only maintained a very small surplus with Bruner, Singapore, and Philippines. With other member countries, China has a significant trade deficit.

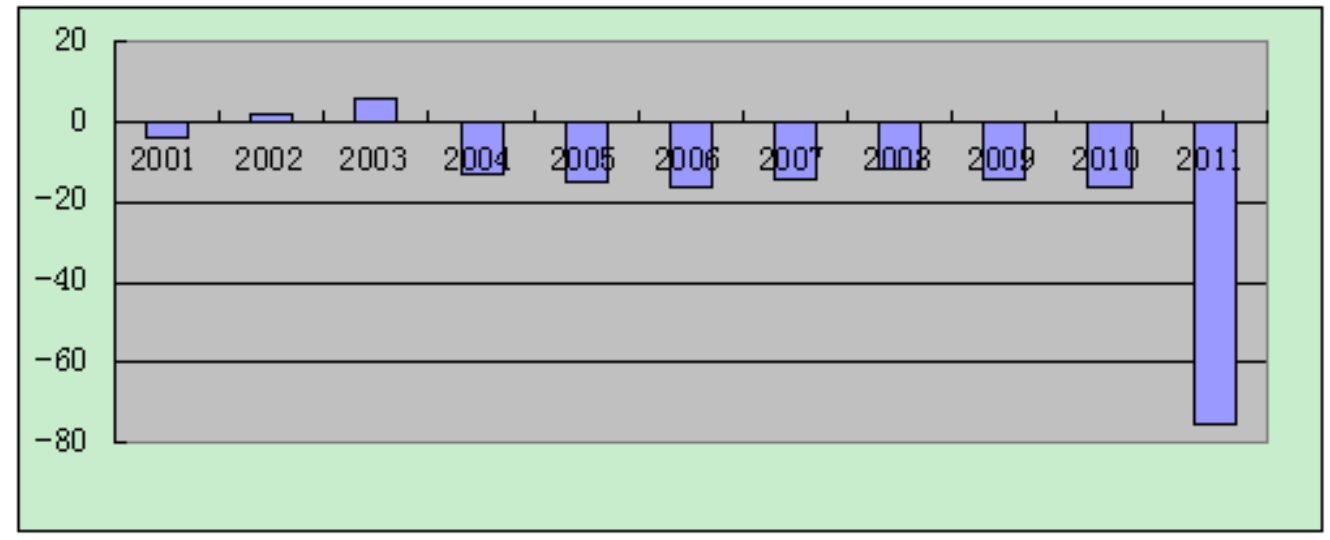

Fig. 2 Chinese deficit of agricultural products trade with ASEANData sources:Chinese Customs

The Agricultural Products Trade between China and ASEAN Shows the Dual Pattern of Competitiveness and Complementarity. Both of the two sides are in Asia, the similar geographical location leads to a certain degree of similarity in their cultures, resulting in similar consume preferences. On January 1, 2010, CAFTA was established which makes the bilateral achieve zero-tariff. These all reflect the competitiveness of bilateral trade. Due to the different natural resources, ASEAN is in tropical climate and China is in temperate climate which make both sides have a certain degree of complementarity in trade varieties. In recent years, ASEAN has expanded trade with China which leads to the growth of Chinese trade deficit. It indicates that China not only has no advantage on many agricultural products but also relies on ASEAN strongly.

\section{Causes of the Dual Pattern of Agricultural Products Trade between China and ASEAN}

\section{Competing Causes of Agricultural Products Trade between China and ASEAN.}

(a) Competitive Location. China and ASEAN both belong to Asia which brings geographic advantages. It is convenient to transport goods between the two sides and both sides' transportation has developed fast. The similar geographical location brings smaller cultural differences, making a similar products trade. Most member countries of ASEAN are traditional agricultural countries that local climate advantage which is suitable for growing plants greatly has promoted the development of agriculture in ASEAN.

(b) Competitive Market. CAFTA has become one of the world's three major free trade zones after it was established. The strong demographic advantage and economic growth of CAFTA have contributed to the growth of bilateral trade and brought a great potential market of the agricultural products trade. China is the major agricultural products trading country of ASEAN. With the zero-tariff trade Chinese agricultural products' competitiveness has enhanced. The increasing population and the growing domestic demand of ASEAN bring their market competitive advantage.

\section{Complementary Causes of Agricultural Products Trade between China and ASEAN.}

(a) Complementary Resource Endowments. Due to different locations, although tropical crops of ASEAN have an absolute advantage to China, China can develop its own advantages of 
temperate crops. ASEAN annually imports a plenty of temperate vegetables, such as apples, pears and other varieties. The complementarity of the bilateral trade also can meet the diversity of social demands. The number of Chinese population is 1.4 billion. With the development of Chinese industrialization process and the policy of returning farmland to forests, Chinese food depends on imports seriously, and the trend will continue to rise in the future. The member countries of ASEAN have an absolute advantage in rice cultivation, which can reach the level of three crops a year. Thailand and Vietnam have also been at the forefront of the global grain exports.

(b) Complementary Agricultural Techniques. Though agriculture in China and ASEAN is in the model of small family business, the Chinese agricultural mechanical level is more advanced than ASEAN, and even has reached the advanced levels of the world. The degree of mechanical level is not high in some member countries of ASEAN, such as Burma, Cambodia, Laos and Thailand, which hindered the development of these countries' agriculture to some extent. Because of the complementary agricultural technology, China can export the appropriate technology and experience to the ASEAN. Western countries are asking for high demands of products, which requires the parties to increase technical cooperation to deal with Western countries' green barriers.

\section{Measures of China-ASEAN Agricultural Trade in the Dual Pattern}

Adjusting the Agricultural Structure and Reducing the Degree of Competition in Agricultural Trade. China has a large number of deficits of agricultural products trade with ASEAN, thus China should be realistic and adjust its industrial structure, reduce the degree of competition with ASEAN. According to Chinese comparative advantage industry, China is supposed to make full use of geographical advantages of temperate climate, develop temperate agricultural products and process products industry, upgrade the technology of agricultural structure, improve the technological content of agricultural products, continue to reduce the cost of production and circulation, introduce the foreign high-quality varieties to cultivate and advanced cultivation techniques, enhance the capacity of storage, preservation and output, pay more attention to pollution-free green food to strengthen its quality assurance, be strict to the development, production, packaging, transportation and sales. It will form China's own characteristics of agricultural products and make Chinese own brand, which will rise Chinese export and improve the international competitiveness of Chinese agricultural products.

Promoting the Bilateral Economic Cooperation and the Development of Agricultural Products Trade Complementarity. With the development of economic globalization, China and ASEAN, depend on different geographic location, product different types of agricultural products and develop complementary trade to solve the problem of resource constraints and share resource. Both sides should set up fairs, cooperative forum and other platform for exchanging information, resource and technology which is good to increase mutual understanding and communication. According to the specific circumstances, China will take the different levels of cooperation with ASEAN, which is conducive to mutual development. China and some member countries of ASEAN have many enterprises whose anti-risk ability is small and information is not comprehensive. These enterprises need the support and assistance from the government. Through the exchange, both sides will not only increase cooperation but also can respond to the rapidly changing international situation better, which is good to achieve a win-win situation.

Conducting Country Cooperation strategy. Due to the different levels of development of ASEAN, China can have different levels' cooperation with different countries. China should increase its agricultural products exports and cooperation with Singapore which has small land area, rapid economic development and lacking foundation for developing agriculture. There are some 
countries, such as Cambodia, Laos and Brunei, whose self-sufficiency is small, but they have huge potential cooperation with China. China can increase the output border trade with Laos because of the neighboring geographical location. China should take advantage of its convenient traffic to promote the communication with Thailand, Philippines, Malaysia and Indonesia which are rich in natural resources. It will improve the quality of Chinese foodstuff and reduce the deficit. For Myanmar and Vietnam which are nearby Chinese southwestern regions, due to the rise of Chinese trade with them in the past few years, China had better increase investment in the two countries to develop agriculture and enhance bilateral cooperation.

\section{Summary}

Based on the study of the dual pattern of agricultural products trade between China and ASEAN, we can make a conclusion that the positive impact of trade cooperation of agricultural products between China and ASEAN is far greater than the negative impact. Due to the highly competitive agricultural products trade between China and ASEAN, both sides should take a variety of forms of cooperation, and adjust the agricultural structure to reduce the competitiveness. According to the differences between the two sides, it is necessary for them to develop the complementarity of trade to promote the development of agriculture and trade.

\section{Acknowledgement}

Here and now, I would like to extend to sincere thanks to all those who have helped me make this thesis possible and better. Firstly, high tribute shall be paid to my honorable supervisor, Dr Liu Shuangqin, for her useful advice and instructive suggestions. Then thanks to my teachers and tutors who have taught me a lot. Finally, I am very grateful to my friends who have offered me direct and indirect help.

\section{References}

[1] Jinping Yu, The Comparative Advantage and Trade Complementarity of China with Main Countries and Areas East Asian, J. World Economy. 5(2003) 33-40.

[2] Roeblano M. Briones, Danilo C. Israel, Enhancing Supply Chain Connectivity and Competitiveness of ASEAN Agricultural Products: Identifying Chokepoints and Opportunities for Improvements, J. Discussion Paper Series. 7(2014) 1-46.

[3] Xianli Xia, Xueli Wu, Research on the Changes of Chinese Agricultural Products Export Trade since China Entered into WTO, J. Huazhong Agricultural University (social science edition). 1(2010) 40-44.

[4] Zhiyu Shi, Empirical Study on the Effects of Chinese Trade with ASEAN Free Trade Area, Doctoral Dissertation, Shanghai, Fudan University library, 2004

[5] Shuquan Huang, Xiguo Yin, The Study of the Trend of Chinese Agricultural Products Exports Structure with ASEAN, J. Asia Pacific Economy. 6(2005) 41-45.

[6] Lingli Lv, The Analysis of the Similarity of Agricultural Products Trade between China and ASEAN, J. World Economic Study. 1(2006) 43-49.

[7] Jian Zhang, Jinbo He, Analysing the Ideas of the Development of Chinese Agricultural Trade, J. Financial Research. 2(2009) 14-18.

[8] Chao Hu, Hai Lu, The Analysis of the Development of Chinese-ASEAN Agricultural Products 
Trade, J. Finance Forum. 4(2009) 26-31.

[9] Jianghong Zhao, The Effect of CAFTA on China Agricultural Products Trade and the Analysis of Countermeasures, J. Chinese Trade. 9(2010) 32-38.

[10] Information on http://www.Aseansec.org. 